\title{
METHODOLOGICAL ASPECTS ON LUMINESCENCE DATING OF FLUVIAL SANDS FROM THE MOSELLE BASIN, LUXEMBOURG
}

\author{
S. CORDIER ${ }^{1,2}$, M. FRECHEN ${ }^{2}$, S. TSUKAMOTO ${ }^{2}$ \\ ${ }^{1}$ Département de Géographie, Université Paris Est-Créteil-Val-de-Marne et UMR 8591 CNRS, \\ 61 avenue du Général de Gaulle, F-94010 Créteil Cedex, France \\ ${ }^{2}$ Leibniz Institut for Applied Geophysics (LIAG), Section 3: Geochronology and Isotope Hydrology, \\ Stilleweg 2, D-30655, Hannover, Germany
}

Received 14 October 2009

Accepted 12 February 2010

\begin{abstract}
Optically stimulated luminescence (OSL) dating of quartz and infrared-stimulated luminescence (IRSL) dating of feldspar were applied to fluvial sands from the lower terrace (M1) of the Moselle valley in Luxembourg (western Europe). The dating results indicated that the aggradation period for the sediments from below the M1 alluvial terrace can be correlated to the Weichselian upper Pleniglacial (MIS 2), which is in good agreement with the general chronostratigraphy of the Moselle terrace staircase. The ages were obtained from small aliquots of quartz and feldspars, using the single aliquot regenerative (SAR) protocol. The equivalent dose determination included a series of tests and the selection of the Minimum Age Model as the most appropriate statistical model. This made it possible to provide a reliable methodological background for further luminescence dating of fluvial sediments from the Moselle basin.
\end{abstract}

Keywords: OSL and IRSL datings, fluvial sediments, Moselle valley, Pleistocene

\section{INTRODUCTION}

Luminescence dating has been recently applied to fluvial deposits all over the world (e.g. Bourke et al., 2003; Cheong et al., 2003; Rittenour et al., 2005; Eriksson et al., 2006; Hanson et al., 2006), especially in Europe (e.g. Loire system, Colls et al., 2001; Peloponnese rivers, Fuchs and Lang, 2001; Pannonian rivers, Nador et al., 2007). In Central Europe, the Rhine-Maas system has also been extensively studied, and particularly in the Upper Rhine Graben and the Lower Rhine area (Wallinga, 2001; Busschers, 2008; Frechen et al,. 2008; Lämmermann-Barthel et al,. 2008; Lauer et al., 2010). The timing of fluvial aggradation periods is actually of great importance for a better understanding of the fluvial response to climate, tectonic and eustatic variations. Fluvial sediments are suitable for the application of optically stimulated luminescence (OSL) dating techniques (Aitken, 1998; Wallinga, 2002; Busschers, 2008), making it possible to estimate the time elapsed since the last exposure to sunlight, which correlates to the deposition age of the fluvial sediments.

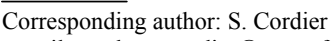

e-mail: stephane.cordier@u-pec.fr

ISSN 1897-1695 (online), 1733-8387 (print) C 2010 GADAM Centre, Institute of Physics, Silesian University of Technology.

All rights reserved.
During the past $\sim 10$ years, attentions have been paid on the timing of past fluvial activity in the Rhine and Moselle river system (e.g. Boenigk and Frechen, 2006; Erkens et al., 2009). Luminescence dating of fluvial sands has been carried out in the basin of the Moselle River, a main left-bank tributary of the Rhine (Cordier et al., 2005; 2006). The dating results allowed to provide a first chronological frame for the youngest fluvial aggradation periods. This made it possible to establish a longitudinal correlation for the Middle and Upper Pleistocene terraces (especially the alluvial terraces M3 and M2, located at +20 and $+10 \mathrm{~m}$ above the bedrock of the present floodplain, respectively) on a $300 \mathrm{~km}$ long valley section, and a correlation between terrace formation and the glaciations in the Moselle upper basin (Vosges Massif). More recent research focused on the lowest alluvial terrace M1 (relative height $3 \mathrm{~m}$ ). This paper reports the methodological investigations of luminescence dating on fluvial sands from M1 in the Luxembourgian Moselle valley.

\section{SITE DESCRIPTION}

The Moselle River rises within the Vosges Mountains. This old massif is of great importance since most of 
the sediments deposited downstream are siliceous: they originated either from the weathering of the Vosges crystalline basement (mainly granites) or from its PermoTriassic sandstones. These sediments are essentially deposited in the marly depressions of the eastern Paris basin, where they form several alluvial basins with wellpreserved terraces staircases, separated by hard-rock thresholds corresponding with cuesta ridges.

The Wintrange area is the largest alluvial basin developed along the German-Luxembourgian border (Fig. 1a), downstream from a gorge section where the river flows through quartzite and sandstone. The basin is located within a syncline depression developed in the Keuper and Liassic marls and clays. While the upper terraces are well preserved on the right bank of the Moselle in Germany, the lower terrace M1 (Cordier et al., 2005) is welldeveloped $3 \mathrm{~m}$ above the present alluvial floodplain (M0) on the left bank in Luxembourg (Fig. 1b). In this latter area, fluvial sediments were intensively exploited in gravel-pits over the past decades, making archaeological and geoarchaeological investigations possible since 1993.

The section under study "Rem VI", described in detail by Naton et al., (2009) is located north of the village of Remerschen. Northing and easting of the section are $49^{\circ} 29^{\prime} 46^{\prime \prime}$ and $6^{\circ} 21^{\prime} 14^{\prime \prime}$, respectively. The fluvial sequence is typical for the M1 alluvial terraces in the Wintrange basin (Cordier et al., 2006). It consists of a succession of three units (Fig. 1c): a coarse lower unit (unit A) up to $5 \mathrm{~m}$ thick, a sandy unit (unit B) 1 to $3 \mathrm{~m}$ thick, and an upper unit (unit C) less than $2 \mathrm{~m}$ thick, which corresponds to an alternation of sandy and silty thin layers.

This alluvial formation is overlain by aeolian and slope deposits. The AMS radiocarbon dating of a juniperus charcoal found at the basis of the slope sediments overlying the fluvial deposits provided an age estimate of $30,770 \pm 300$ B.P. (Naton et al., 2009). Due to its stratigraphic position in a colluvial unit, this age does not indicate the timing of aggradation for the M1 terrace. We therefore applied luminescence dating using quartz and potassium-rich feldspar which enable to date terrace sediments directly.

\section{SAMPLING STRATEGY, SAMPLE PREPARA- TION AND PREVIOUS LABORATORY RE- SEARCH}

Four samples were taken from homogeneous sandy layers to ensure an homogenous radiation field in the
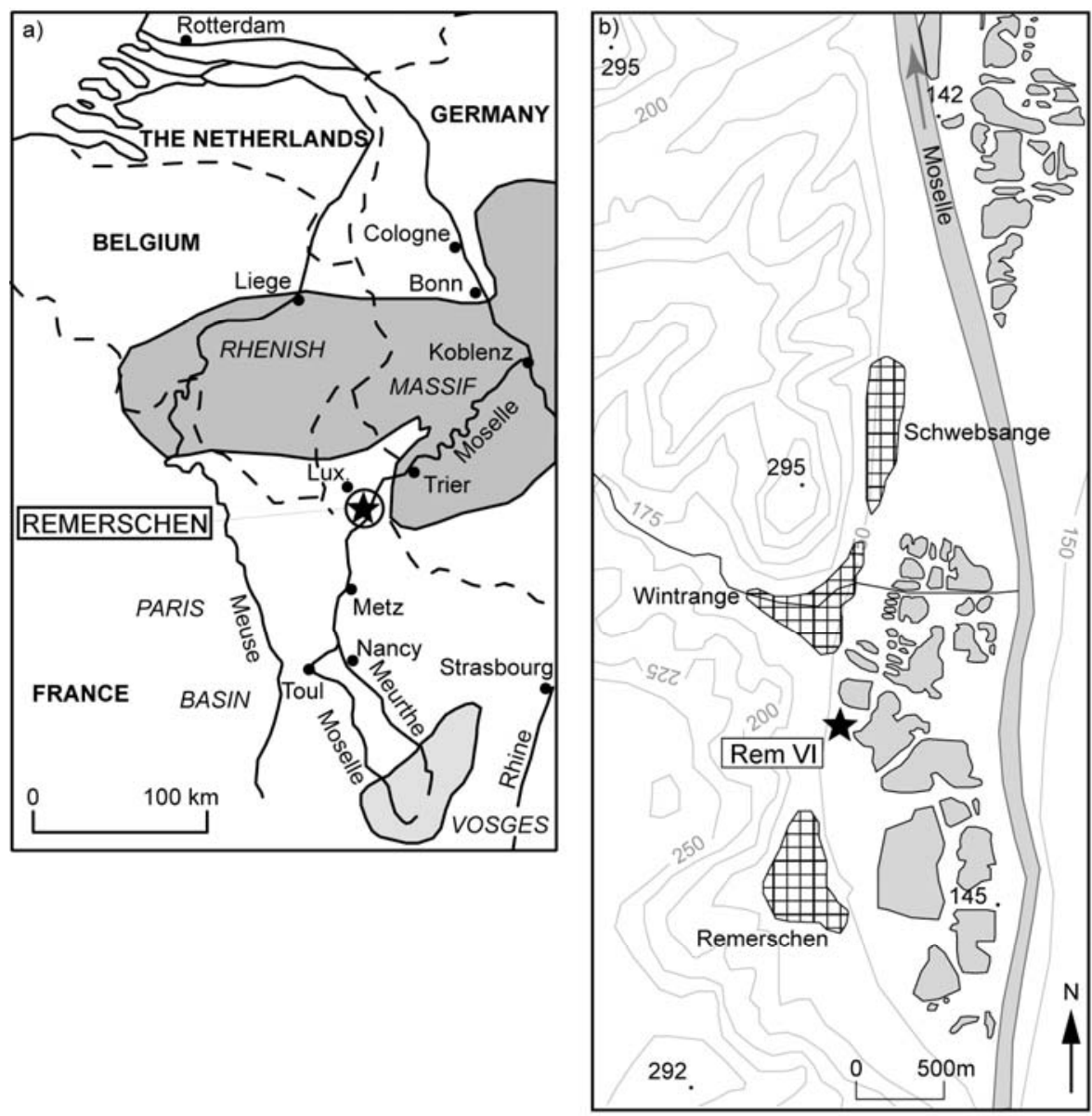

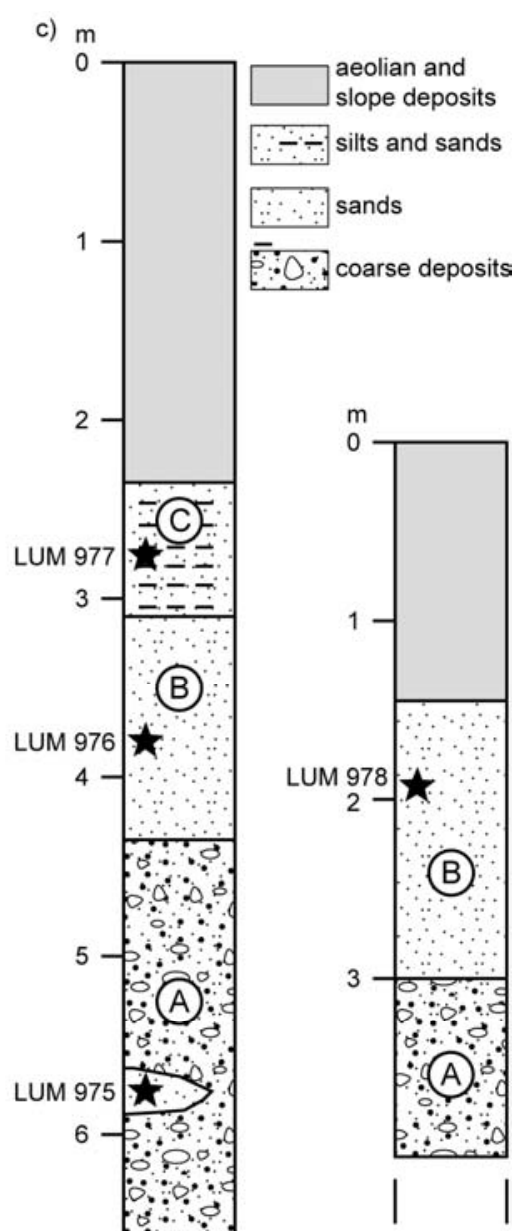

Fig. 1. Map and graphic logs of the studied section : a)general map of the Moselle basin; b)map of the Wintrange basin; c)section Rem-VI with location of the samples taken for luminescence dating. 
sediment body under study: Sample LUM 975 was taken from a sandy lens on top of coarse unit A, samples LUM 976 and 978 were collected from unit B, and sample LUM 977 from unit C (Fig. 1c). Samples LUM 975, LUM 976 and LUM 977 are more or less located in the same profile, while LUM 978 has been collected about 20 $\mathrm{m}$ east.

Sediments from surrounding of the luminescence sampling positions were used to determine the dose-rates. The samples were dried, homogenized, stored for one month to establish radioactive equilibrium between ${ }^{222} \mathrm{Rn}$ and ${ }^{222} \mathrm{Ra}$. The radionuclide concentrations (uranium, thorium and potassium) were measured at least for 24 hours using a gamma-spectrometer with a high purity germanium detector. The dose rate was calculated using the Adele program (Kulig, 2005). The results are presented in Table 1, assuming for feldspars grains a potassium content of $12.5 \pm 0.5 \%$ (Huntley and Baril, 1997) and an alpha efficiency of $0.15 \pm 0.05$ as proposed by S. Balescu and M. Lamothe (1994) for fluvial sediments.

The samples for the determination of the equivalent doses $\left(D_{e}\right)$ were prepared using routine procedures in the luminescence-laboratory of the Leibniz Institute for Applied Geophysics in Hannover (Germany). The preparation took place under subdued red light conditions and included a first sieving to separate the grain size fraction between 100 and $150 \mu \mathrm{m}$ (Fig. 2). The sand was subsequently exposed to chemical treatment with $\mathrm{HCl}$, sodiumoxalate, and $\mathrm{H}_{2} \mathrm{O}_{2}(30 \%)$, to remove carbonates, aggregates and organic materials, respectively. Heavy liquid with the densities of $2.70,2.62$ and 2.58 were used to separate heavy minerals, plagioclase, quartz, and potassium-rich feldspar. The quartz fraction was treated with concentrated HF (40\%) for about 60 minutes to dissolve remaining feldspar grains and to etch the alpha-exposed outer rim of the grains. It was then sieved again to remove grains whose diametre was significantly reduced by the etching. The quartz and potassium-rich feldspar grains were finally mounted on stainless steel discs.

The first measurements focused on sand from sample LUM 976 and 977. They were performed as routine measurements using both the SAR (for potassium-rich feldspars and quartz) and the multiple aliquot additive dose (MAAD) protocols, using 20 large aliquots $(6 \mathrm{~mm}$ diameter) including a few thousands grains. The results (Table 2) should be considered as not relevant, because the measurements lack the laboratory tests (dose recovery and preheat plateau tests) and the fading correction for the feldspars. Furthermore, the use of large aliquots and of the weighted mean (on ca. 20 aliquots for each sample) to calculate the $D_{e}$ may have led to age overestimation.
For all these reasons it was decided to start new measurements to get more accurate $\mathrm{D}_{\mathrm{e}}$ by avoiding averaging (Wallinga, 2002).

\section{NEW DETERMINATIONS OF THE EQUIVA- LENT DOSE $\left(D_{\mathrm{e}}\right)$}

The second analyses focused on samples LUM 975 (located in the lower part of the sequence, to date the beginning of the aggradation as close as possible), LUM 977 (for comparisons to be done with the first ones) and LUM 978. The measurements were performed on samples using small aliquots $(2 \mathrm{~mm}$ diameter, a few tens of grains), and the single aliquot regenerative procedure (SAR) was applied for both quartz and feldspars (Table 3) (Murray and Wintle, 2000; 2003). The measurements were performed using a Risø TL/OSL reader (model DA 20) fitted with blue LEDs (emitting at 470 $\mathrm{nm}$ ) for OSL stimulation and IR LEDs (emitting at 870 $\mathrm{nm}$ ) for IR stimulation. The detection filters used were the Hoya U-340 for quartz samples, and a combination of Schott BG-39 and Corning 7-59 for feldspars. All the sequences for quartz included a measure of the residual IRSL to detect feldspar contamination. Aliquots which showed a bad depletion ratio (more than 10\%) were not considered for the $\mathrm{D}_{\mathrm{e}}$ estimation following the suggestion of Duller (2003).

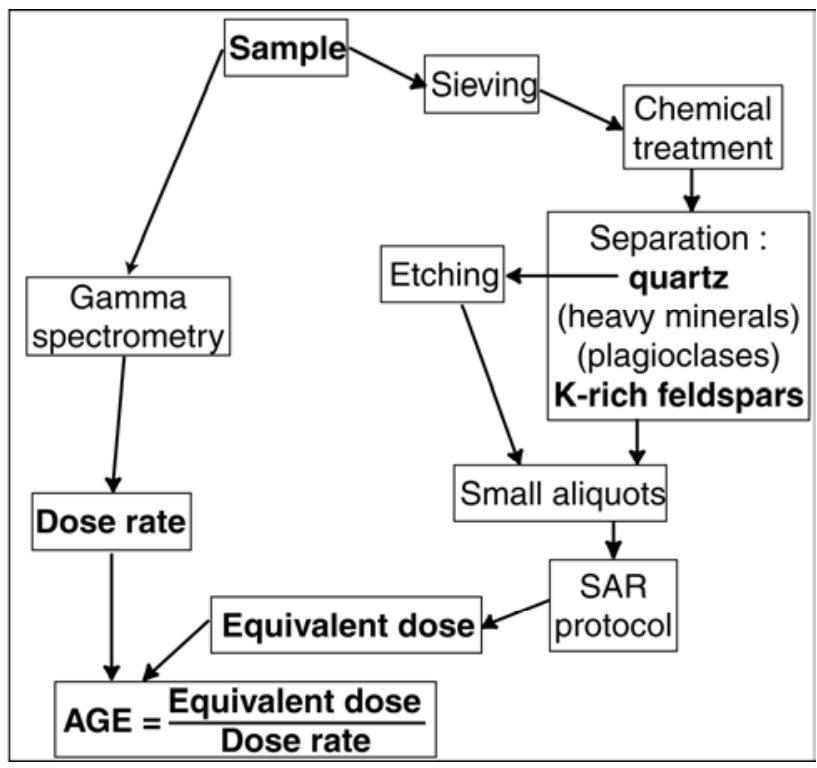

Fig. 2. Summary of the laboratory procedures for the luminescence dating.

Table 1. Dosimetry of the studied samples.

\begin{tabular}{lcccccc}
\hline Sample & U-content $(\mathrm{ppm})$ & Th-content (ppm) & K-content (\%) & $\begin{array}{c}\text { Cosmic Dose } \\
\text { (Gy/ka) }\end{array}$ & $\begin{array}{c}\text { Dose rate (Gy/ka) } \\
\text { quartz }\end{array}$ & $\begin{array}{c}\text { Dose rate (Gy/ka) } \\
\text { feldspar }\end{array}$ \\
\hline 975 & $1.09 \pm 0.01$ & $3.79 \pm 0.02$ & $1.81 \pm 0.01$ & 0.11 & $1.97 \pm 0.11$ & $2.47 \pm 0.13$ \\
976 & $1.13 \pm 0.02$ & $4.08 \pm 0.04$ & $2.09 \pm 0.02$ & 0.11 & - & - \\
977 & $1.68 \pm 0.02$ & $6.60 \pm 0.05$ & $2.23 \pm 0.02$ & 0.13 & - & $3.13 \pm 0.17$ \\
978 & $1.67 \pm 0.02$ & $6.11 \pm 0.04$ & $2.13 \pm 0.01$ & 0.15 & $2.51 \pm 0.14$ & $3.03 \pm 0.18$ \\
\hline
\end{tabular}


Table 2. Summary of the first luminescence results for samples LUM 976 and 977 . The OSL measurements were performed with a $260^{\circ} \mathrm{C}$ preheat and $160^{\circ} \mathrm{C}$ cutheat. The IRSL SAR used $290^{\circ} \mathrm{C}(10 \mathrm{~s})$ for preheat and $210^{\circ} \mathrm{C}(10 \mathrm{~s})$ for cutheat. The IRSL MAAD measurements included a $260^{\circ} \mathrm{C}$ preheat for $60 \mathrm{~s}$.

\begin{tabular}{|c|c|c|c|c|c|c|c|c|c|}
\hline \multirow[b]{2}{*}{ Sample } & \multicolumn{3}{|c|}{ OSL (SAR) } & \multicolumn{3}{|c|}{ IRSL (SAR) } & \multicolumn{3}{|c|}{ IRSL (MAAD) } \\
\hline & $\mathrm{De}(\mathrm{Gy})$ & $\mathrm{Da}$ (Gy/ka) & Age (ka) & $\mathrm{De}(\mathrm{Gy})$ & $\mathrm{Da}$ (Gy/ka) & Age (ka) & $\mathrm{De}(\mathrm{Gy})$ & $\mathrm{Da}$ (Gy/ka) & Age (ka) \\
\hline 976 & $71.2 \pm 2.2$ & $2.2 \pm 0.2$ & $32.2 \pm 2.4$ & $61.0 \pm 0.9$ & $2.9 \pm 0.2$ & $21.0 \pm 1.5$ & $58.8 \pm 2.2$ & $2.9 \pm 0.2$ & $20.3 \pm 1.6$ \\
\hline 977 & $101.6 \pm 7.3$ & $2.6 \pm 0.2$ & $39.3 \pm 3.9$ & $67.5 \pm 1.4$ & $3.3 \pm 0.2$ & $20.3 \pm 1.5$ & $56.4 \pm 2.4$ & $3.3 \pm 0.2$ & $17.0 \pm 1.4$ \\
\hline
\end{tabular}

\section{Quartz}

A dose recovery test (Murray and Wintle, 2003) was first performed for LUM 978 with a given dose of 73.4 $\mathrm{Gy}$, at various preheat temperatures $\left(20^{\circ} \mathrm{C}\right.$ steps $)$ ranging from 200 to $300^{\circ} \mathrm{C}$ with a cut-heat at $200^{\circ} \mathrm{C}$. The ratio recovered/given dose was close to unity between $240^{\circ} \mathrm{C}$ and $260^{\circ} \mathrm{C}$ (Fig. 3), and the former temperature was selected for the subsequent measurements. The recycling ratios are systematically consistent with unity (ranging from 0.98 to 1.05 ) and the recuperation never exceeds $2 \%$ (Fig. 3).

A set of aliquots from the same sample was applied to another dose recovery test with varying cut-heat temperature between $160^{\circ} \mathrm{C}$ and $240^{\circ} \mathrm{C}$ (with a preheat at $240^{\circ} \mathrm{C}$ ). The results (Fig. 4) clearly show that $D_{e}$ is insensitive to cut-heat temperature, resulting in the selection of the $200^{\circ} \mathrm{C}$ temperature for cut-heat. The reliability of these measuring parameters was confirmed by a doserecovery test undertaken on aliquots from samples LUM 975, LUM 976 and LUM 977. Fig. 5 shows that the measured/given dose is systematically close to unity (ranging from 1.02 to 1.04). We consequently performed the SAR protocol, as described in Table $\mathbf{3}$, including a $280^{\circ} \mathrm{C}$ blue LEDs stimulation at the end of each SAR cycle to minimize recuperation.
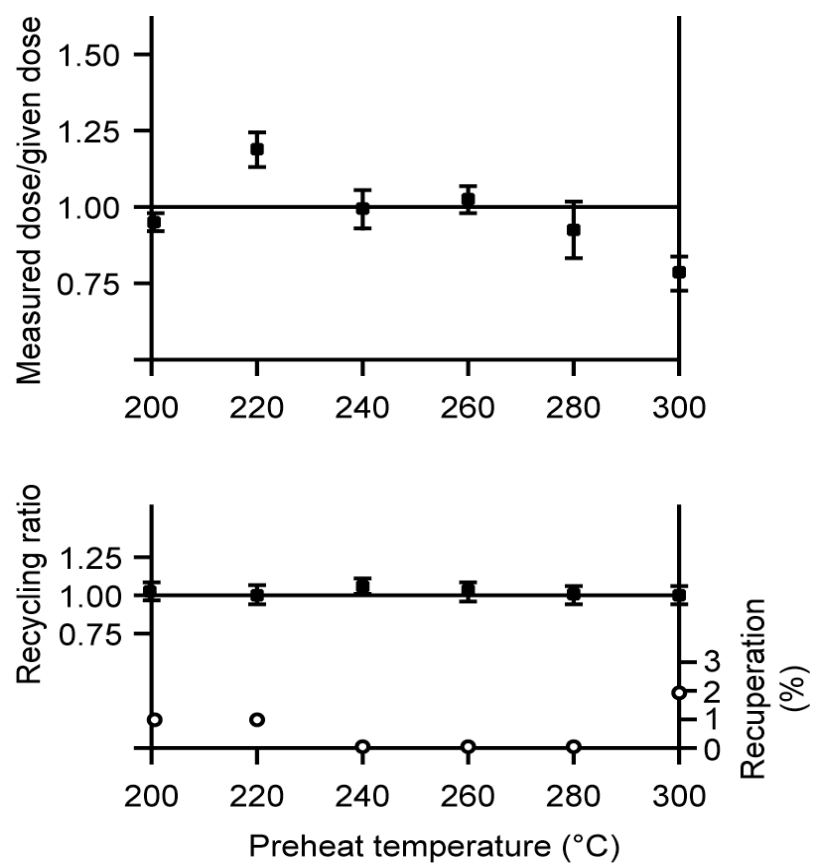

Fig. 3. Results of the preheat/dose-recovery test performed for quartz from sample LUM 978, including the recycling ratio and recuperation.

\section{Feldspar}

A SAR protocol, using the identical preheat before both OSL $\left(\mathrm{L}_{\mathrm{x}}\right)$ and test dose OSL $\left(\mathrm{T}_{\mathrm{x}}\right)$ measurements, was used to estimate the $\mathrm{D}_{\mathrm{e}}$ values for feldspars (Blair et al., 2005; Table 3). The result of a dose recovery test for all

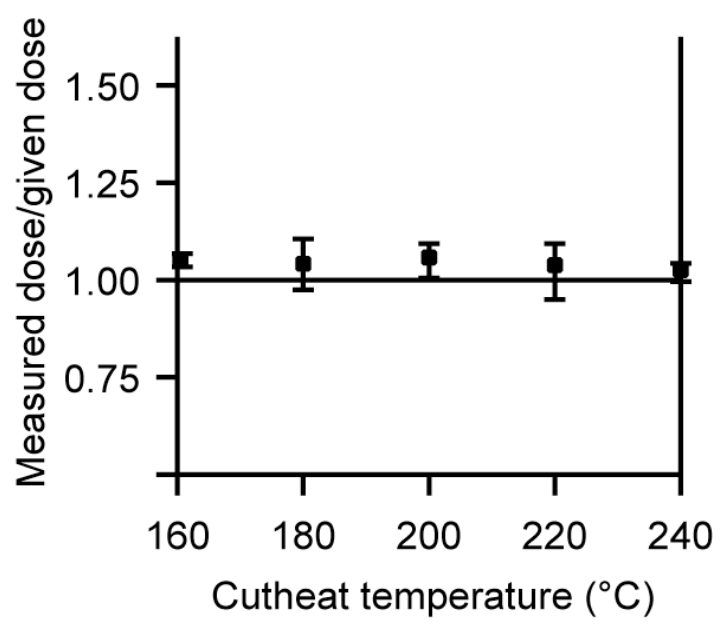

Fig. 4. Results of the cut-heat test performed for quartz from sample LUM 978.
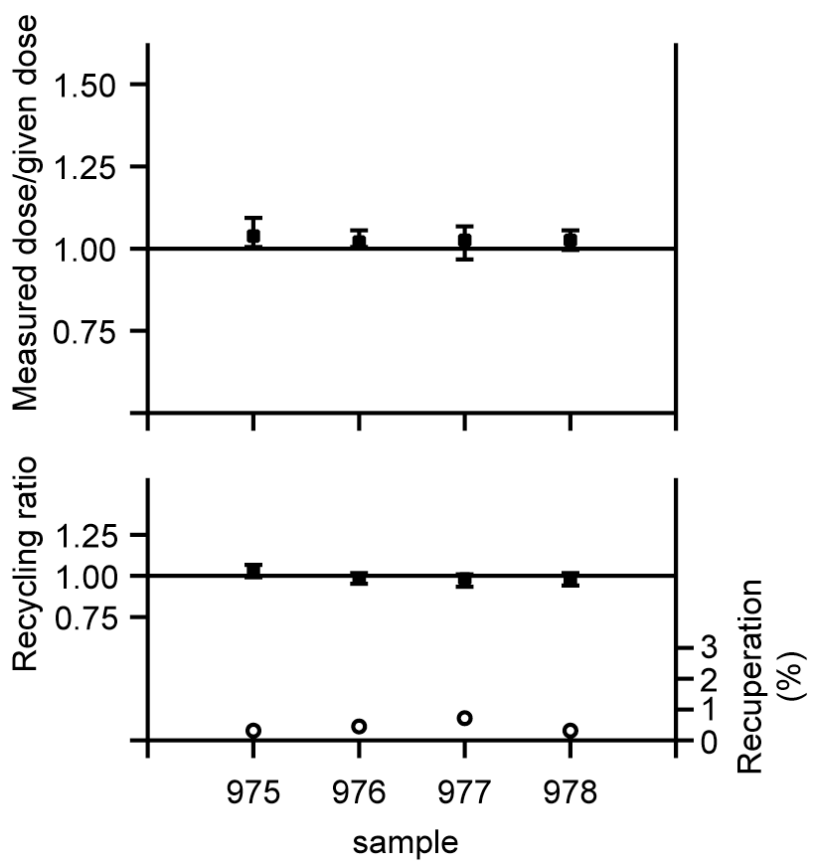

Fig. 5. Results of the dose recovery test (including the recycling ratio and recuperation) performed for quartz from others samples using the same $\mathrm{PH}$ and $\mathrm{CH}$ temperatures as for LUM 978. 
Table 3. The SAR protocol applied for this study to quartz and feldspar grains.

\begin{tabular}{|c|c|c|c|}
\hline \multicolumn{2}{|r|}{ the SAR protocol applied to coarse-grain quartz } & \multicolumn{2}{|r|}{ the SAR protocol applied to coarse-grain feldspar } \\
\hline 1 & Preheat at $240^{\circ} \mathrm{C}$ for $10 \mathrm{~s}$. , heating rate $5^{\circ} \mathrm{C} / \mathrm{s}$. & 1 & Preheat at $260^{\circ} \mathrm{C}$ for $10 \mathrm{~s}$. , heating rate $5^{\circ} \mathrm{C} / \mathrm{s}$. \\
\hline 2 & Blue-LED stimulation at $125^{\circ} \mathrm{C}$ for $40 \mathrm{~s}$. & 2 & IR diodes stimulation at $50^{\circ} \mathrm{C}$ for $100 \mathrm{~s}$. \\
\hline 3 & Give test-dose $=100$ s. $(=12.2 \mathrm{~Gy})$ & 3 & Give test-dose $=100 \mathrm{~s} .(=12.2 \mathrm{~Gy})$ \\
\hline 4 & Cut-heat at $200^{\circ} \mathrm{C}$ for $0 \mathrm{~s}$., heating rate $5^{\circ} \mathrm{C} / \mathrm{s}$. & 4 & Heating at $260^{\circ} \mathrm{C}$ for $10 \mathrm{~s}$., heating rate $5^{\circ} \mathrm{C} / \mathrm{s}$. \\
\hline 5 & Blue-LED stimulation at $125^{\circ} \mathrm{C}$ for $40 \mathrm{~s}$. & 5 & IR diodes stimulation at $50^{\circ} \mathrm{C}$ for $100 \mathrm{~s}$. \\
\hline 6 & Blue-LED stimulation at $280^{\circ} \mathrm{C}$ for $40 \mathrm{~s}$. & 6 & $\begin{array}{l}\text { Give various regenerative doses ( } 300 \mathrm{s.,}, 600 \mathrm{s.}, 900 \mathrm{~s} . \text { and } \\
1200 \mathrm{~s} \text {.) and repeat step } 1 \text { to } 5\end{array}$ \\
\hline 7 & $\begin{array}{l}\text { Give various regenerative doses ( } 300 \text { s., } 600 \text { s., } 900 \text { s. and } \\
1200 \text { s.) and repeat step } 1 \text { to } 6\end{array}$ & 7 & $\begin{array}{l}\text { Give a regenerative dose }=0 \mathrm{~s} \text {. and repeat step } 1 \text { to } 5 \text { to check } \\
\text { recuperation }\end{array}$ \\
\hline & Checking of recuperation and recycling: & 8 & $\begin{array}{l}\text { Give a low regenerative dose and repeat step } 1 \text { to } 5 \text { to check } \\
\text { recycling }\end{array}$ \\
\hline 8 & Give a regenerative dose $=0 \mathrm{~s}$. and repeat step 1 to 6 & & \\
\hline 9 & $\begin{array}{l}\text { Give a repeated regenerative dose and repeat step } 1 \text { to } 6 \\
\text { Checking of feldspar contamination: }\end{array}$ & & \\
\hline 10 & Give the same regenerative dose & & \\
\hline 11 & Preheat at $240^{\circ} \mathrm{C}$ for $10 \mathrm{~s}$., heating rate $5^{\circ} \mathrm{C} / \mathrm{s}$. & & \\
\hline 12 & IR diodes stimulation at $125^{\circ} \mathrm{C}$ for $100 \mathrm{~s}$. & & \\
\hline
\end{tabular}

the three samples using a preheat at $260^{\circ} \mathrm{C}$ for $10 \mathrm{~s}$ was satisfactory (Fig. 6). All measurements were then carried out using the preheat at $260^{\circ} \mathrm{C}$ for $10 \mathrm{~s}$. A fading test was subsequently performed for 6 aliquots applying the method of Auclair et al., (2003) and the correction procedure by Huntley and Lamothe (2001) in order to estimate the fading rate and corrected ages, respectively.

\section{Determination of the $D_{e}$ value based on statistical models}

The $\mathrm{D}_{\mathrm{e}}$ measurements were performed for quartz samples LUM 975 (55 aliquots) and LUM 978 (35 aliquots), and for feldspar samples LUM 975 (54 aliquots), 977 (52 aliquots) and 978 (12 aliquots) using the SAR protocol (Table 3). The results are presented in Fig. 7. They clearly show a significant scatter in the $D_{e}$ values which may be considered as typical for fluvial sediments. A greater scattering is observed for the quartz samples (skewness ranging between 1.73 and 3.49) in comparison with the feldspars (skewness ranging between -0.32 and 1.54). The feldspar $D_{\mathrm{e}}$ values are probably more averaged than those of quartz, because one can assume that only one or two grains have emitted light in the quartz small aliquots whereas many more grains have contributed for feldspar. The other possible explanation is different origin of these minerals; it is expected that most of the feldspar grains originated from the Vosges Massif (located at about $200 \mathrm{~km}$ upstream from the Remerschen section), and can hence be considered as "relatively well- bleached". On the contrary the quartz has a more complex origin: the majority of the grains originated from the Vosges Massif, but some of them may also originated
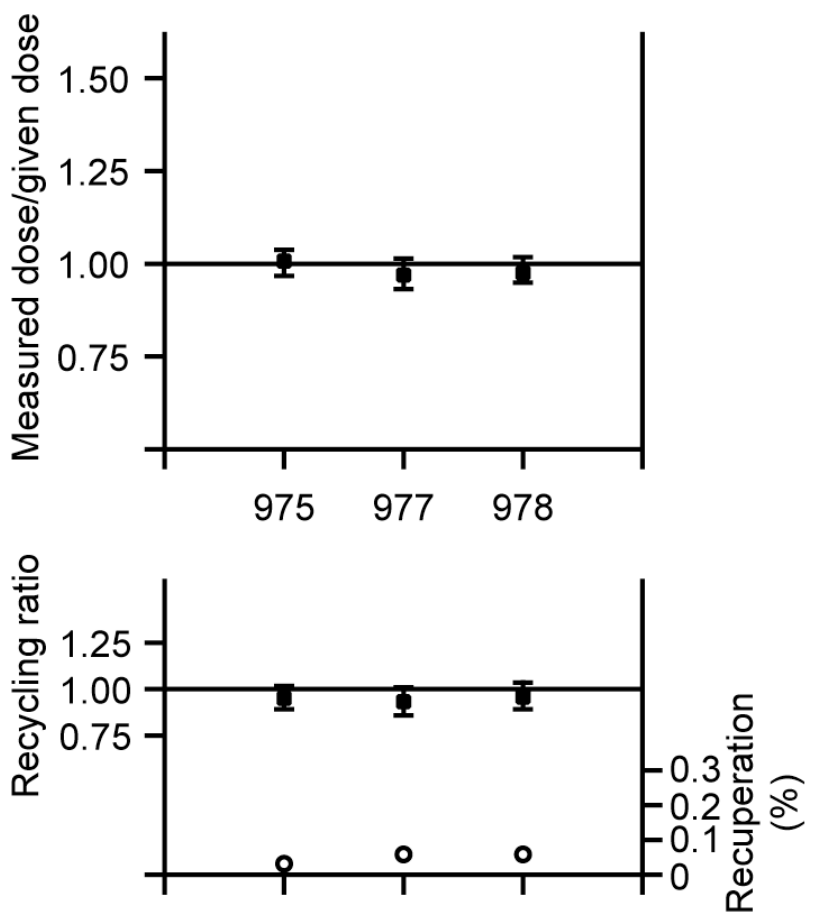

Fig. 6. Results of the dose recovery test performed for feldspars.

Table 4. Determination of the most likely equivalent dose $D_{e}$ using several numerical parameters and statistical models.

\begin{tabular}{|c|c|c|c|c|}
\hline \multirow[b]{2}{*}{ Sample } & \multicolumn{4}{|c|}{$\mathrm{De}(\mathrm{Gy})$} \\
\hline & mean & weighted mean & central age model & minimum age model \\
\hline \multicolumn{5}{|c|}{ quartz } \\
\hline 975 & $77.2 \pm 3.4$ & $60.4 \pm 0.5$ & $73.3 \pm 3.0$ & $48.6 \pm 2.8$ \\
\hline 978 & $87.0 \pm 5.9$ & $73.9 \pm 0.8$ & $80.9 \pm 3.1$ & $61.9 \pm 3.5$ \\
\hline \multicolumn{5}{|c|}{ feldspar } \\
\hline 975 & $54.1 \pm 0.4$ & $53.7 \pm 0.3$ & $54.0 \pm 0.4$ & $52.4 \pm 1.0$ \\
\hline 977 & $72.6 \pm 0.7$ & $71.6 \pm 0.4$ & $72.2 \pm 0.6$ & $68.6 \pm 1.3$ \\
\hline 978 & $61.0 \pm 0.6$ & $60.8 \pm 0.6$ & $60.8 \pm 1.9$ & $60.5 \pm 1.0$ \\
\hline
\end{tabular}




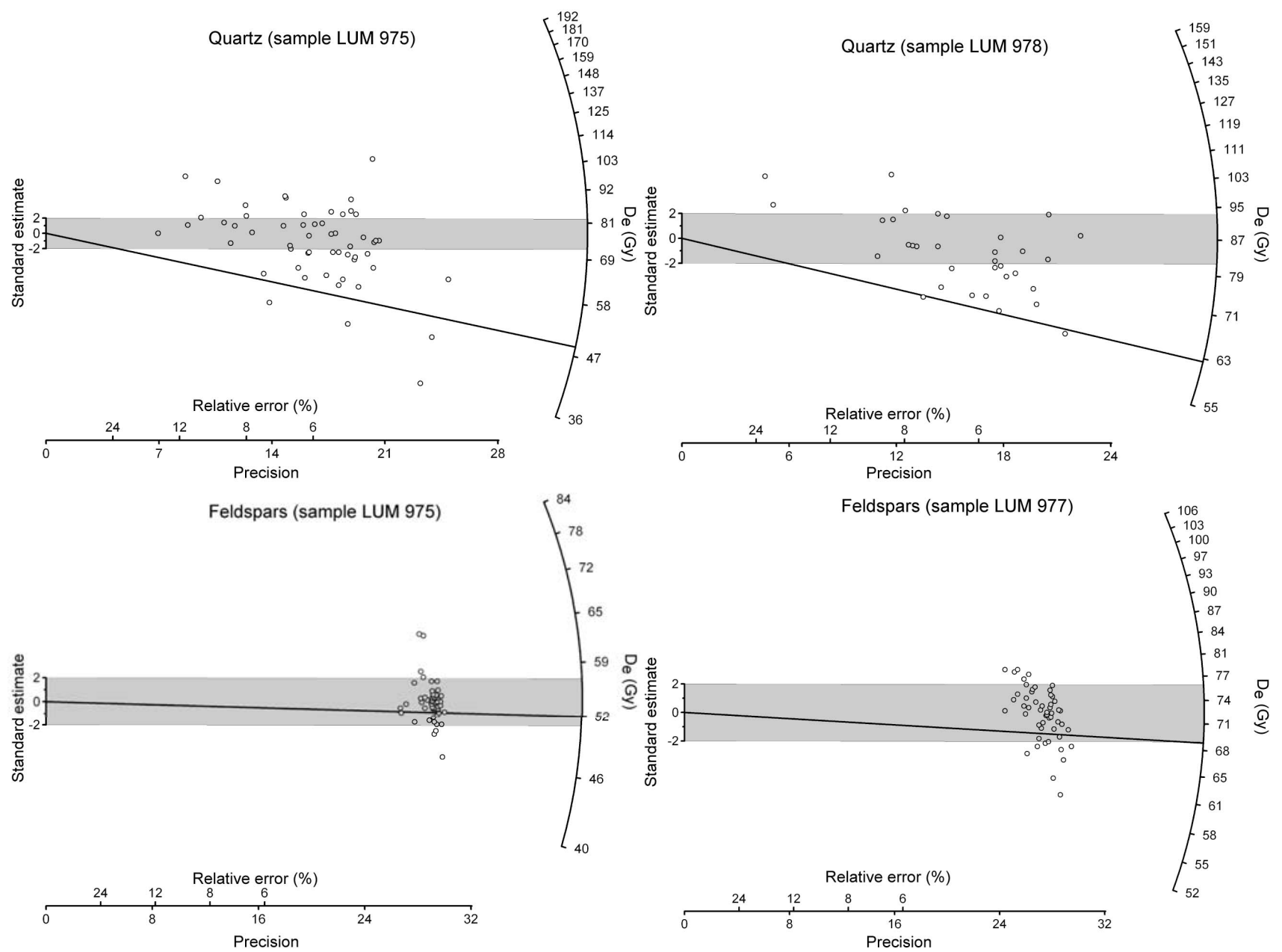

Fig. 7. Radial plots of the $D_{e}$ values for sample LUM 975, LUM 977 (feldspars) and LUM 978 (quartz). The reference value is the mean $D_{e}$ and the grey area corresponds with the two standard deviations. The dark line corresponds with the $D_{e}$ calculated using the Minimum Age Model.

from the sandstone and quartzite located a few kilometres upstream from the section under study, hence being potentially not fully bleached.

The determination of the $\mathrm{D}_{\mathrm{e}}$ was made using both the Central Age Model and the Minimum Age Model (Galbraith et al., 1999). While the former calculates the weighted mean but also takes into consideration the additional dispersion resulting from the measurement uncertainties, the latter makes it possible to identify the most bleached aliquots. The results are presented in Table 4 and compared with the mean and the weighted mean. The dataset clearly indicates the significance of

Table 5. Luminescence age estimates for samples from the Remerschen section.

\begin{tabular}{|c|c|c|c|c|c|c|}
\hline \multirow{2}{*}{ grain type (nb of aliq.) } & \multicolumn{2}{|c|}{ Minimum age model } & \multicolumn{2}{|c|}{ Central age model } & \multicolumn{2}{|c|}{ Weighted mean } \\
\hline & $\mathrm{De}(\mathrm{Gy})$ & Age (ka) & $\mathrm{De}(\mathrm{Gy})$ & Age (ka) & $\mathrm{De}(\mathrm{Gy})$ & Age (ka) \\
\hline \multicolumn{7}{|c|}{ LUM 975} \\
\hline quartz OSL (55) & $48.6 \pm 2.8$ & $24.6 \pm 1.9$ & $73.3 \pm 3.0$ & $37.1 \pm 2.5$ & $60.4 \pm 0.3$ & $32.3 \pm 1.7$ \\
\hline & & $21.2 \pm 1.2$ & & $21.9 \pm 1.1$ & & $21.7 \pm 1.1$ \\
\hline & & $27.4 \pm 1.6$ & & $28.2 \pm 1.5$ & & $28.1 \pm 1.5$ \\
\hline feldspar IRSL (54) & $52.4 \pm 1.0$ & $(2.7 \pm 0.1)$ & $54 \pm 0.4$ & $(2.7 \pm 0.1)$ & $53.7 \pm 0.3$ & $(2.7 \pm 0.1)$ \\
\hline \multicolumn{7}{|c|}{ LUM 977} \\
\hline & & $21.9 \pm 1.2$ & & $23.1 \pm 1.2$ & & 22. $9 \pm 1.2$ \\
\hline & & $28.0 \pm 1.7$ & & $29.4 \pm 1.2$ & & $29.2 \pm 1.7$ \\
\hline feldspar IRSL (52) & $68.6 \pm 1.4$ & $(2.6 \pm 0.2)$ & $72.2 \pm 0.6$ & $(2.6 \pm 0.2)$ & $71.6 \pm 0.4$ & $(2.6 \pm 0.2)$ \\
\hline \multicolumn{7}{|c|}{ LUM 978} \\
\hline quartz OSL (35) & $61.9 \pm 3.5$ & $24.6 \pm 1.3$ & $80.9 \pm 3.1$ & $32.2 \pm 2.1$ & $73.9 \pm 0.8$ & $29.4 \pm 1.6$ \\
\hline & & $20.0 \pm 1.1$ & & $20.1 \pm 1.3$ & & $20.1 \pm 1.2$ \\
\hline & & $26.0 \pm 1.8$ & & $25.9 \pm 1.9$ & & $25.8 \pm 1.7$ \\
\hline feldspar IRSL (12) & $60.5 \pm 1.0$ & $(2.7 \pm 0.2)$ & $60.9 \pm 1.9$ & $(2.7 \pm 0.2)$ & $60.8 \pm 0.6$ & $(2.7 \pm 0.2)$ \\
\hline
\end{tabular}

feldspar ages : italic $=$ uncorrected, bold $=$ corrected ages. Fading correction $\left(\mathrm{g}_{2 \text { days }}\right)$ is in brackets 
the skewness for quartz dose distribution (see above), as the dose estimates are significantly different between the two models. Since incomplete bleaching is expected to be the reason for the skewed dose distribution, the Minimal Age Model is considered to be the most appropriate in order to select only bleached grains at deposition (Rodnight, 2008). We regard the Central Age Model ages (which are unsurprisingly closer to the mean value) as maximum depositional ages for the quartz sands, as these ages may be overestimated due to incompletely bleached grains. In contrast, the weak scattering of the $\mathrm{D}_{\mathrm{e}}$ distribution for the feldspars is confirmed by the consistent ages observed between the different calculation methods (Table 4 and 5).

\section{AGE ESTIMATES AND DISCUSSION}

The age estimates derived from the above-mentioned $\mathrm{D}_{\mathrm{e}}$ values using the Minimum Age Model are presented in Table 5. The age estimates for quartz sands are in agreement within the error range of the fading corrected feldspar ages (Table 5). The fading rates $\left(\mathrm{g}_{2 \text { days }}\right)$ obtained for the three samples show a uniform value between 2.6 and $2.7 \%$ per decade. The results are also consistent with the stratigraphy, as the deepest sample (LUM 975) shows an older age estimate than the others. Only sample 977 shows an older IRSL age, despite it is located above LUM 975.

These age estimates are in good agreement with the expected ages for sediments from below terrace M1, which was assumed to have been formed during MIS 2, since the upper terrace M2 is allocated to MIS 4-3 and the present floodplain M0 has a Lateglacial to Holocene age (MIS 1, Cordier et al., 2005; 2006). These results indicate that the main terrace incision took place at the warm-tocold transition (e.g. beginning of the Weichselian Upper Pleniglacial for incision from terrace M2 to terrace M1), as has been already mentioned for older terraces. It should be emphasized that in contrast with the older terraces (e.g. terraces M2, M3 or M4, Cordier et al., 2006) which spanned a whole climate cycle, the terrace M1 was formed only during one cold stage (the interglacial deposits being preserved in the present floodplain M0). The weak relative height of the terrace M1 $(+3 \mathrm{~m})$ above M0 should hence be interpretated as the result of a strongest cold-to-warm erosion during the Lateglacial, enabling the formation of two stepped alluvial floodplains.

This research confirms the importance of OSL and IRSL techniques to date fluvial sediments, as recently shown for surrounding areas such as the Meuse (Wallinga 2001, Schokker et al. 2005) or the Rhine (Frechen et al. 2008). This is particularly important for the Moselle basin where independent age control (in particular using radiocarbon) are unfortunately very uncommon due to the lack of suitable material.

\section{CONCLUSION}

While the first analyses mostly focused on the determination of numerical ages (Cordier et al., 2005; 2006), our new research carried out at the LIAG in Hannover made it possible to develop a methodological robust basis for the luminescence dating of fluvial samples from the Moselle basin. More accurate and precise $\mathrm{D}_{\mathrm{e}}$ values have been obtained by incorporating thorough performance tests (preheat plateau, dose-recovery tests, and fading correction for feldspars) for the SAR protocol, and by using small aliquots (in spite of large aliquots) including statistical models to select the appropriate $\mathrm{D}_{\mathrm{e}}$ values from well-bleached grains. This made it possible to confirm the allocation of the lower terrace M1 to the MIS 2, since OSL and IRSL datings yielded consistent ages.

This methodological basis is able to be used as a reference for further luminescence dating studies in the Moselle basin, e.g. in the Sarre and Meurthe valleys. This should make it possible to obtain a more accurate chronology for the terrace staircase in the Moselle basin (including the present floodplain), enabling a better understanding of internal and external forcing on fluvial evolution, and more precise correlations with the Rhine aggradation periods.

\section{ACKNOWLEDGEMENTS}

The authors thank the two anonymous reviewers for their comments which helped improve the manuscript. Stéphane Cordier gratefully acknowledges the DAAD (German Academic Exchange Service) for the a threemonths grant, allowing him to work at the Leibniz Institute of Applied Geophysics in Hannover. Dr. Astrid Techmer (LIAG) is acknowledged for providing the first dating results. Access to the Rem VI gravel pit and sampling were made possible thanks to Alphonse and JeanPierre Hein, Marc Wiltzius and Fernando Soares (Hein company S.A.), and to Henri-Georges Naton and Laurent Brou (Musée National d'Histoire et d'Art du Luxembourg), respectively.

\section{REFERENCES}

Aitken MJ, 1998. Introduction to optical dating. Oxford university press Oxford: $267 \mathrm{pp}$

Auclair M, Lamothe M and Huot S, 2003. Measurement of anomalous fading for feldspar IRSL using SAR. Radiation Measurements 37(4-5): 487-492, DOI 10.1016/S1350-4487(03)00018-0.

Balescu S and Lamothe M, 1994. Comparison of TL and IRSL age estimates of feldspar coarse grain from waterlain sediments. Quaternary Science Reviews 13(5-7): 437-444, DOI 10.1016/02773791(94)90056-6.

Boenigk W and Frechen M, 2006. The Pliocene and Quaternary fluvial archives of the Rhine system. Quaternary Science Reviews, 25(56): 550-574, DOI 10.1016/j.quascirev.2005.01.018.

Blair MW, Yukihara EG and McKeever SWS, 2005. Experiences with single-aliquot procedures using coarse-grain feldspars. Radiation Measurements 39(4): $\quad 361-374, \quad$ DOI 10.1016 j.radmeas.2004.05.008.

Bourke MC, Child A and Stokes S, 2003. Optical age estimates for hyperarid fluvial deposits at Homeb, Namibia. Quaternary Science Reviews 22(10-13): 1099-1103, DOI 10.1016/S0277-3791(03)00085-4.

Busschers FS, 2008. Unravelling the Rhine. Response of a fluvial system to climate change, sea-level oscillation and glaciation, Ph.D. Geology of the Netherlands: $186 \mathrm{pp}$

Cheong CS, Hong DG, Lee KS, Kim JW, Choi JH, Murray AS, Chwae UImCB, Chang CJ and Chang HW, 2003. Determination of slip rate by optical dating of fluvial deposits from the Wangsan fault, SE Korea. Quaternary Science Reviews 22(10-13): 1207-1211, DOI 10.1016/S0277-3791(03)00020-9.

Colls AE, Stokes S, Blum MD and Straffin E, 2001. Age limits on the Late Quaternary evolution of the upper Loire River. Quaternary 
Science Reviews 20(5-9): 743-750, DOI 10.1016/S02773791(00)00048-2.

Cordier S, Frechen M, Harmand D and Beiner M, 2005. Middle and Upper Pleistocene fluvial evolution of the Meurthe and Moselle valleys in the Paris basin and the Rhenish Massif. Quaternaire 16: 203-217.

Cordier S, Harmand D, Frechen M and Beiner M, 2006. Fluvial system response to Middle and Upper Pleistocene climate change in the Meurthe and Moselle valleys (Paris basin and Rhenish Massif). Quaternary Science Reviews 25(13-14): 1460-1474, DOI 10.1016/j.quascirev.2005.11.007.

Duller GAT, 2003. Distinguishing quartz and feldspar in single grain luminescence measurements. Radiation Measurements 37(2): 161165, DOI 10.1016/S1350-4487(02)00170-1.

Eriksson MG, Olley JM, Kilham DR, Pietsch T and Wasson R, 2006. Aggradation and incision since the very late Pleistocene in the Naas River, south-eastern Australia. Geomorphology 81(1-2): 6688, DOI 10.1016/j.geomorph.2006.04.001.

Erkens G, Dambeck R, Volleberg KP, Bouman M, Bos JAA, Cohen KM, Wallinga $J$ and Hoek WZ, 2009. Fluvial terrace formation in northern Upper Rhine Graben during the last 20000 years as a result of allogenic control and autogenic evolution. Geomorphology $103 \quad$ (3): 476-495, DOI 10.1016/ j.geomorph.2008.07.021.

Frechen M, Ellwanger D, Rimkus D and Techmer A, 2008. Timing of Medieval Fluvial aggradation at Bremgarten in the southern Upper Rhine Graben - a test for luminescence dating.- Eiszeitalter und Gegenwart (Quaternary Science Journal) 57: 411-432.

Fuchs M and Lang A, 2001. OSL dating of coarse-grain fluvial quartz using single-aliquot protocols on sediments from NE Peloponnese, Greece. Quaternary Science Reviews 20(5-9): 783-787, DOI 10.1016/S0277-3791(00)00040-8.

Galbraith RF, Roberts RG, Laslett GM, Yoshida H and Olley JM, 1999. Optical dating of single and multiple grains of quartz from Jinmium rock shelter, northern Australia: part I. Experimental design and statistical models. Archaeometry 41(2): 339-364, DOI 10.1111/j.1475-4754.1999.tb00987.x.

Hanson PR, Mason JA and Goble RJ, 2006. Fluvial terrace formation along Wyoming's Laramie Range as a response to inscreased late Pleistocene flood magnitudes. Geomorphology 76(1-2): 12-25, DOI 10.1016/j.geomorph.2005.08.010.

Huntley DJ and Lamothe M, 2001. Ubiquity of anomalous fading in Kfeldspars and the measurment and correction for it in optical dating.Canadian Journal of Earth Sciences 38(7): 1039-1106, DOI 10.1139/cjes-38-7-1093.

Huntley DJ and Baril MR, 1997. The K content of the K-feldspars being measured in optical dating or in thermoluminescence dating. Ancient $T L 15,11-13$.
Kulig, G., 2005. Erstellung einer Auswertesoftware zur Altersbestimmung mittels Lumineszenzverfahren unter besonderer Berücksichtigung des Einflusses radioaktiver Ungleichgewichte in der ${ }^{238} \mathrm{U}$-Zerfallsreihe. Bakkalaureusarbeit, Inst. F. Informatik, TU Bergakademie Freiberg (2005) 35 pp.

Lämmermann-Barthel J, Neeb I, Hinderer M and Frechen M, 2009. Last glacial to Holocene fluvial aggradation and incision in the southern upper rhine graben: climatic and neotectonic controls. Quaternaire 1:25-34.

Lauer T, Frechen M, Hoselmann C and Tsukamoto S, 2010. Fluvial aggradation phases in the Upper Rhine Graben-New insights by quartz OSL dating. Proceedings of the Geologists' Association, in press, DOI 10.1016/j.pgeola.2009.10.006.

Murray AS and Wintle AG, 2000. Luminescence dating of quartz using an improved single-aliquot regenerative-dose protocol. Radiation Measurements 32(1): 57-73, DOI 10.1016/S1350-4487(99)00253-X.

Murray AS and Wintle AG, 2003. The single aliquot regenerative dose protocol: potential for improvements in reliability. Radiation Measurements 37(4-5): $377-381$, DOI $10.1016 / \mathrm{S} 1350$ 4487(03)00053-2.

Nador A, Thamo-Bozso Magyari A and Babinszki E, 2007. Fluvial responses to tectonics and climate change during the Late Weichselian in the eastern part of the Pannonian Basin (Hungary) Sedimentary Geology $202 \quad(1-2): \quad 174-192, \quad$ DOI 10.1016/j.sedgeo.2007.03.001.

Naton HG, Cordier S, Brou L, Damblon F, Frechen M, Hauzeur A, Le Brun-Ricalens F and Valotteau F, 2009. Fluvial evolution of the Moselle valley in Luxembourg during Late Pleistocene and Holocene: palaeoenvironment and human occupation Quaternaire 1: 81-92.

Rittenour TM, Goble RJ and Blum MD, 2005. Development of an OSL chronology for Late Pleistocene channel belts in the lower Mississippi valley, USA. Quaternary Science Reviews 24(23-24): 25392554. DOI 10.1016/j.quascirev.2005.03.011.

Rodnight H, 2008. How many equivalent dose values are needed to obtain a reeproducible distribution? Ancient TL 26 (1).

Schokker J, Cleveringa P, Murray AS, Wallinga J and Westerhoff WE, 2005. An OSL dated Middle and Late Quaternary sedimentary record in the Roer Valley Graben (southeastern Netherlands). Quaternary Science Reviews 24 (20-21): 2243-2264 DOI 10.1016/j.quascirev.2005.01.010.

Wallinga J, 2001. The Rhine-Meuse system in a new light: optically stimulated luminescence dating and its application to fluvial deposits.Netherlands Geographical studies 290: $180 \mathrm{pp}$

Wallinga J, 2002. Optically stimulated luminescence dating of fluvial deposits: a review. Boreas 31(4): 303-322, DOI 10.1080/030094802320942536. 